\title{
Effect of storage on the bioactive compounds, nutritional composition and sensory acceptability of pitanga jams
}

\author{
Thaise Mariá TOBAL ${ }^{1 \star}$ (D), Lais Veras RODRIGUES ${ }^{1}$
}

\begin{abstract}
Conventional and diet pitanga jams were prepared to assess the stability of bioactive compounds over 320 days of storage. The diet jam exhibited a higher nutritional value and bioactive compound content than the conventional jam. None of the tested jam formulations exhibited major changes in physical and nutritional characteristics during storage. However, the bioactive compound content and antioxidant activity were significantly reduced after processing pulp into jam and over the course of storage. Storage also had an effect on the sensory quality of the products. The conventional jam had higher flavour acceptance, whereas the diet jam exhibited lower scores for colour, appearance and overall acceptance.
\end{abstract}

Keywords: carotenoids; ascorbic acid; phenols; anthocyanins; antioxidant activity; component modification.

Practical Application: Stability of bioactive compounds over 320 days of storage.

\section{Introduction}

The consumption of antioxidant-rich food is an important means for the prevention of cardiovascular diseases, cancer (Kris-Etherton et al., 2002; Serafini et al., 2002) and neurodegenerative diseases (Di-Matteo \& Esposito, 2003), and fruits are considered sources of these compounds (Cieślik et al., 2006).

Jam production is of interest for the food industry because it allows for the use of healthy fruits during the harvest season that are otherwise unusable, adding value to the raw material, increases the shelf life of these agricultural products, making fruit-derived bioactive compounds available all year round. Furthermore, the food industry has invested in the development of fruit-based products, which not only provide nutrition but aid in the prevention and control of diseases without compromising their acceptance. This advancement is attributable to implemented technology and improved ingredients, such as the development of diet and light products (Derivi \& Mendez, 2001; Granada et al., 2005).

The anthocyanin, flavonol and carotenoid contents of pitanga make it a source of antioxidant, and its cultivation and consumption should be encouraged (De Lima et al., 2002). Pitanga has an exotic and appealing flavour, and it is an excellent candidate for the processing and valorisation of fruit resources (Consolini \& Sarubbio, 2002; De Lima et al., 2002). However, these antioxidant compounds are generally unstable and can be degraded during some stages of fruit processing (Ewald et al., 1999). Specifically, light, temperature and storage time can interfere with the stability of vitamin C, carotenoids and phenolic compounds (Cardoso et al., 1997; Yamashita et al., 2003; Zepka $\&$ Mercadante, 2009). The processing of fruit into jam, the storage time and storage temperature and the jam composition can affect the amounts of these compounds (Moura et al., 2012; Kopjar et al., 2016).

Due to the significant number of biologically active compounds in pitanga, its poor industrial exploitation and the instability of these compounds during processing and storage, two pitanga jam formulations were developed in the present study. Conventional and diet jams were made to assess the effects of storage on the carotenoid, phenolic compound, ascorbic acid and anthocyanin contents as well as on the antioxidant activity, nutritional composition and sensory acceptability.

\section{Materials and methods}

\subsection{Materials}

The fruits were acquired at a local market in São Paulo, Brazil, and pectins were purchased from CPKelco (São Paulo, São Paulo/ Brazil). The remaining ingredients used in the jam formulations were donated by Nutramax (Catanduva, São Paulo/ Brazil). The reagents used for chemical analyses were purchased from JKALAB and Sigma-Aldrich (Campo Grande, Mato Grosso do Sul/ Brazil).

\subsection{Jam preparation}

The fruits were selected and then sanitised by immersion in a sodium hypochlorite solution (200 ppm) for $15 \mathrm{~min}$. The pulp was removed with a pulp extractor. The conventional jam was prepared with $60 \%$ pulp, $40 \%$ sucrose and $1 \%$ high-methoxyl pectin previously hydrated with water at $70{ }^{\circ} \mathrm{C}$ ( $1: 10$ ratio). The mixture was cooked until the final soluble solids content reached $67^{\circ}$ Brix. The $\mathrm{pH}$ of the pulp was then adjusted with $0.05 \%$ citric acid. 
The diet jam was prepared with $12 \mathrm{~kg}$ of pulp, $0.8 \%$ low-methoxyl pectin, $0.5 \%$ sorbitol, $0.5 \%$ maltitol, $0.3 \%$ xanthan gum, $0.8 \%$ polydextrose, $0.0075 \%$ sucralose, $0.015 \%$ acesulfame potassium, $40 \mathrm{mg} / \mathrm{g}$ tricalcium phosphate pectin, $0.015 \%$ citric acid and $0.05 \%$ potassium sorbate. The jam was prepared in the following steps: pulp concentration by cooking until $20^{\circ} \mathrm{Brix}$; addition of thickeners until $23^{\circ} \mathrm{Brix}$; addition of sweeteners; addition of firming agent, preservative and acidifier at $25^{\circ} \mathrm{Brix}$; and homogenisation. The jam was hot-filled into sterilised glass containers with screw caps and immediately cooled, labelled and stored at room temperature away from light.

The physical and nutritional characteristics and sensory acceptability were analysed after jam production and at day 320 of storage. The determination of bioactive compounds and antioxidant activity were performed after processing and at days $10,30,50,80,110,140,170,200,230,260,290$ and 320 of storage.

\subsection{Physical and nutritional characterisation}

The moisture content was determined by the gravimetric method at $105^{\circ} \mathrm{C}$, and lipids were extracted using the Bligh-Dyer method. The protein content was determined using the micro-Kjeldahl method, and the ash content was obtained by incineration at $550{ }^{\circ} \mathrm{C}$. The $\mathrm{pH}$ was determined using an electrochemical method. The dietary fibre content was determined by the 985.29 enzymatic gravimetry method (Association of Official Analytical Chemists, 1997), and soluble solids were quantified with an Abbe refractometer (Association of Official Analytical Chemists, 1990). The carbohydrate content was calculated by difference, and the energy value was calculated from the sum of the calories obtained after multiplying the mean values (in grams) of carbohydrates, lipids and proteins using the Atwater factors of $4 \mathrm{kcal}, 9 \mathrm{kcal}$ and $4 \mathrm{kcal}$, respectively.

\subsection{Analysis of bioactive compounds and antioxidant activity}

The carotenoid content was determined according to a method described by Rodriguez-Amaya (2001) with modifications, and the total anthocyanin content was determined by the $\mathrm{pH}$ differential method (Kuskoski et al., 2006). The antioxidant activity was determined using a method based on the reduction of the 2,2-diphenyl-1-picrylhydrazyl (DPPH)-free radical (Brand-Williams et al., 1995). The total phenolic compounds were determined by the Folin-Ciocalteu method as described by Kiralp \& Toppare (2006). The ascorbic acid content was determined with the Tillmans method using a solution of 2,6-dichlorophenolindophenol that was previously standardised with an ascorbic acid solution (Association of Official Analytical Chemists, 1990).

\subsection{Sensory analysis}

Sensory acceptability was assessed with a structured nine-point hedonic scale with scores ranging from 1 ("like extremely") to 9 ("dislike extremely") evaluating the attributes of colour, appearance, aroma, flavour, texture and overall acceptance (Meilgaard et al., 1999). The acceptance test was administered in individual booths with 120 untrained judges of both sexes who agreed to participate in the study and who signed an informed consent form approved by the Ethics Committee on Human Research (process no. 1.005.045). Samples were served as follows: with cream crackers in a monadic and balanced order, in containers labelled with random three-digit numbers, in individual booths, and under white light (Meilgaard et al., 1999).

\subsection{Statistical analysis}

The results obtained were subjected to an analysis of variance (ANOVA), and means were compared with Tukey's test $(p \leq 0.05)$ using Origin 8.0 software (OriginLab, Northampton, Massachusetts, USA).

\section{Results and discussion}

\subsection{Physical and nutritional characterisation}

The physical and nutritional analysis showed that the total soluble solids content, moisture content and $\mathrm{pH}$ of the conventional pitanga jam (Table 1) were all within the range for most jams (total soluble solids > 62\% w/w, Lago et al., 2006 and Raj et al., 2017; moisture content up to $65 \% \mathrm{w} / \mathrm{w}$ and $\mathrm{pH}$ up to 3.4, Rababah et al., 2011; Lago et al., 2006). The diet jam exhibited a pH of 3.63 and $22.95^{\circ} \mathrm{Brix}$, which was greater than the values reported for blackberry jam prepared with different sweeteners (Mota, 2007).

The higher water content of the diet jam might be due to the hydrocolloids present in the formulation, which contribute

Table 1. Physical and nutritional characteristics of pitanga jams after preparation and after 320 days of storage (mean \pm standard deviation).

\begin{tabular}{|c|c|c|c|c|}
\hline \multirow{2}{*}{ Pitanga jam } & \multicolumn{2}{|c|}{ Conventional } & \multicolumn{2}{|c|}{ Diet } \\
\hline & Preparation & Storage & Preparation & Storage \\
\hline Moisture (g/100 g) & $21.70 \pm 0.50^{\mathrm{a}}$ & $23.97 \pm 1.26^{\mathrm{a}}$ & $74.94 \pm 0.23^{\mathrm{a}}$ & $74.18 \pm 0.52^{\mathrm{a}}$ \\
\hline Protein (g/100 g) & $0.70 \pm 0.31^{\mathrm{a}}$ & $0.93 \pm 0.16^{\mathrm{a}}$ & $1.41 \pm 0.26^{\mathrm{a}}$ & $1.56 \pm 0.08^{\mathrm{a}}$ \\
\hline Carbohydrate (g/100 g) & $76.7 \pm 0.05^{\mathrm{a}}$ & $73.64^{\mathrm{a}}$ & $21.06 \pm 0.07^{\mathrm{a}}$ & $21.76^{\mathrm{a}}$ \\
\hline Lipid (g/100 g) & $0.55 \pm 0.07^{\mathrm{a}}$ & $0.93 \pm 0.38^{\mathrm{a}}$ & $1.61 \pm 0.09^{\mathrm{a}}$ & $1.59 \pm 0.01^{\mathrm{a}}$ \\
\hline Ash (g/100 g) & $0.35 \pm 0.18^{\mathrm{a}}$ & $0.53 \pm 0.09^{\mathrm{a}}$ & $0.98 \pm 0.01^{\mathrm{a}}$ & $0.91 \pm 0.03^{\mathrm{a}}$ \\
\hline Dietary fibre (g/100 g) & $2.28 \pm 0.01^{\mathrm{a}}$ & $1.03 \pm 0.05^{b}$ & $1.58 \pm 0.01^{\mathrm{a}}$ & $1.45 \pm 0.02^{\mathrm{a}}$ \\
\hline Energy value (Kcal/100 g) & $305.43^{\mathrm{a}}$ & $302.53^{\mathrm{b}}$ & $98.05^{\mathrm{a}}$ & $101.79^{\mathrm{b}}$ \\
\hline $\mathrm{pH}$ & $3.44 \pm 0.01^{\mathrm{a}}$ & $3.24 \pm 0.10^{\mathrm{a}}$ & $3.63 \pm 0.01^{\mathrm{a}}$ & $3.340 .02 \pm^{b}$ \\
\hline Total soluble solids ( ${ }^{\circ}$ Brix) & $64.00 \pm 0.01^{\mathrm{a}}$ & $63.05 \pm 0.07^{\mathrm{b}}$ & $22.95 \pm 1.34^{\mathrm{a}}$ & $21.05 \pm 0.07^{\mathrm{a}}$ \\
\hline
\end{tabular}

Different letters in the same row indicate significant differences between the storage time for each jam $(p<0.05)$ 
to higher water retention in the product (Toneli et al., 2005). The ash and protein contents are related to the use of sweeteners and to hydrocolloid composition, respectively (Polesi et al., 2011). Further, the replacement of sucrose, which has high a carbohydrate content and contributes to the energy value, led to a product with low energy value (Table 1).

The jam formulations remained virtually unchanged after 320 days of storage, with small reductions in $\mathrm{pH}$ in the diet jam and in the ${ }^{\circ}$ Brix in the conventional jam. Reduction in $\mathrm{pH}$ during storage has also been found in conventional and light blackberry jams after 90 days (Nachtigall et al., 2004) as well as in strawberry, cherry, apricot, fig and orange jams after 5 months (Rababah et al., 2011). A decrease in soluble solids was also found by Mota (2006) during storage of blackberry jam, but the value was still within the ideal value for jams despite this change. During storage, the soluble solids content and $\mathrm{pH}$ can increase, decrease or remain stable; these variations are related to the processing conditions (Nachtigall et al., 2004).

\subsection{Analysis of bioactive compounds and antioxidant activity}

The pulp exhibited a higher content of total phenolic compounds and higher antioxidant activity compared with the conventional jam (Table 2), which has also been found in other studies on jam (Rababah et al., 2011; Rutz et al., 2012; Souza et al., 2015) and fruit juice (Wu et al., 2010). However, the antioxidant activity was higher in the diet jam (Table 2) given that lower values (g sample/g DPPH; an expression of the final antioxidant activity in the present study) indicate higher antioxidant activities of the analyte.

The total carotenoid content was significantly higher in the pulp than in the jams (Table 2), and the replacement of sucrose in the diet jam was related to the increased percentage of pulp in the final product, thus resulting in a higher carotenoid content. Other studies have also found a reduction in carotenoid content after the processing of fruits into jam (Maciel et al., 2009; Rutz et al., 2012).

The conventional jam had a higher ascorbic acid content (Table 2), which might be due to the amount of this component added to the jam formulation. Processing reduced the initial anthocyanin content of the pulp (Table 2); this effect was also observed in seven formulations in a study that prepared jam from different types of blackberry cultivars (Mota, 2006). This reduction may have been due to factors such as available oxygen, the ascorbic acid content and heating (Bobbio \& Bobbio, 2003).

The effect of storage on the bioactive compound content and antioxidant activity of the pitanga jams is shown in Figure 1.
Carotenoid content of the conventional jam (C) decreased over the course of 110 days and then remained constant until 320 days of storage, with a total decrease of $48.95 \%$. In the diet jam (D), changes were observed up to 290 days of storage. However, the greatest decrease occurred during the initial 50 days, and the total decrease was $66.25 \%$. Carotenoids are susceptible to several degradation reactions during food processing and storage, and this is directly correlated with the concentrations of oxygen, metals, enzymes, unsaturated lipids, pro-oxidants or antioxidants as well as the exposure to light, type of carotenoid, physical state of the carotenoids present in the food, severity of thermal treatment, packaging material and storage conditions. This degradation can lead to a loss of colour of the food and to a reduction in the biological activity of the carotenoids (Zepka \& Mercadante, 2009).

A decrease in phenol content was detected after 140 days in the conventional jam and after 10 days in the diet jam, and the decrease was progressive until 320 days with a final decrease of $48.01 \%$ and $57.43 \%$, respectively. The decrease in phenolic compounds during storage has been documented in other studies on jam, including a decrease in phenols during the first 60 days of storage in diet cubiu jam (Yuyama et al., 2008) and after 135 days of storage in orange jam (Kopjar et al., 2016). This degradation is probably due to oxidation and polymerisation reactions (Laorko et al., 2013).

The vitamin C content of the conventional jam decreased over the course of 140 days, after which it remained constant until 320 days of storage. In contrast, the diet jam exhibited changes in vitamin $\mathrm{C}$ content after 80 days of storage. The total decrease in vitamin $C$ content was $58.6 \%$ and $38.71 \%$ in the conventional and diet jams, respectively. The decrease in the ascorbic acid content during 350 days of storage has been reported for fruit juices as follows: a $45.12 \%$ decrease in unsweetened whole acerola juice bottled by hot fill (Freitas et al., 2006a); 23.61\% and $35.95 \%$ decreases in acerola juice bottled by the hot fill and aseptic methods, respectively (Freitas et al., 2006b); and 25.65\% and $26.74 \%$ decreases in tropical cashew juice bottled by the hot fill and aseptic methods, respectively (Costa et al., 2003). Vitamin C is thermolabile and is quickly destroyed by light. Thus, vitamin $\mathrm{C}$ is used as an indicator to measure the effects of processing on nutrient retention. The losses in vitamin $\mathrm{C}$ content vary according to the type of processing and equipment used, and its degradation also leads to the formation of dark pigments (Yamashita et al., 2003).

Anthocyanins exhibited a significant decrease after 50 days of storage in the conventional jam reaching a total decrease of $37.5 \%$. This result was consistent with the findings of Mota (2006), who observed a reduction in anthocyanin content in blackberry

Table 2. Bioactive compounds and antioxidant activity in pitanga pulp and conventional and diet jams (mean \pm standard deviation).

\begin{tabular}{|c|c|c|c|c|c|}
\hline Sample & $\begin{array}{c}\text { Total carotenoids } \\
(\mu \mathrm{g} / \mathrm{g} \text { sample })\end{array}$ & $\begin{array}{c}\text { Total phenols } \\
\text { (mg GAE/100 mL extract) }\end{array}$ & $\begin{array}{c}\text { Ascorbic acid } \\
\text { (mg vit } \mathrm{C} / 100 \mathrm{~g} \text { sample) }\end{array}$ & $\begin{array}{c}\text { Anthocyanins } \\
\text { (mg/100 g sample) }\end{array}$ & $\begin{array}{l}\text { Antioxidant activity } \\
\text { (g sample/g DPPH) }\end{array}$ \\
\hline Pitanga pulp & $2338.82 \pm 91.01^{\mathrm{a}}$ & $824.64 \pm 25.39^{\mathrm{a}}$ & $25.06 \pm 2.17^{\mathrm{a}}$ & $0.24 \pm 0.01^{\mathrm{a}}$ & $1522.61 \pm 11.85^{\mathrm{a}}$ \\
\hline Conventional jam & $231.73 \pm 1.65^{\mathrm{b}}$ & $469.36 \pm 32.42^{b}$ & $28.65 \pm 0.01^{\mathrm{b}}$ & $0.08 \pm 0.03^{\mathrm{b}}$ & $2384.93 \pm 185.7^{\mathrm{b}}$ \\
\hline Diet jam & $1160.53 \pm 26.39^{c}$ & $793.97 \pm 67.98^{\mathrm{a}}$ & $22.01 \pm 0.01^{\mathrm{a}}$ & $0.01 \pm 0.02^{c}$ & $1467.63 \pm 5.29^{c}$ \\
\hline
\end{tabular}

Mean values followed by different letters in the same column differ significantly according to Tukey's test $(p \leq 0.05)$. 

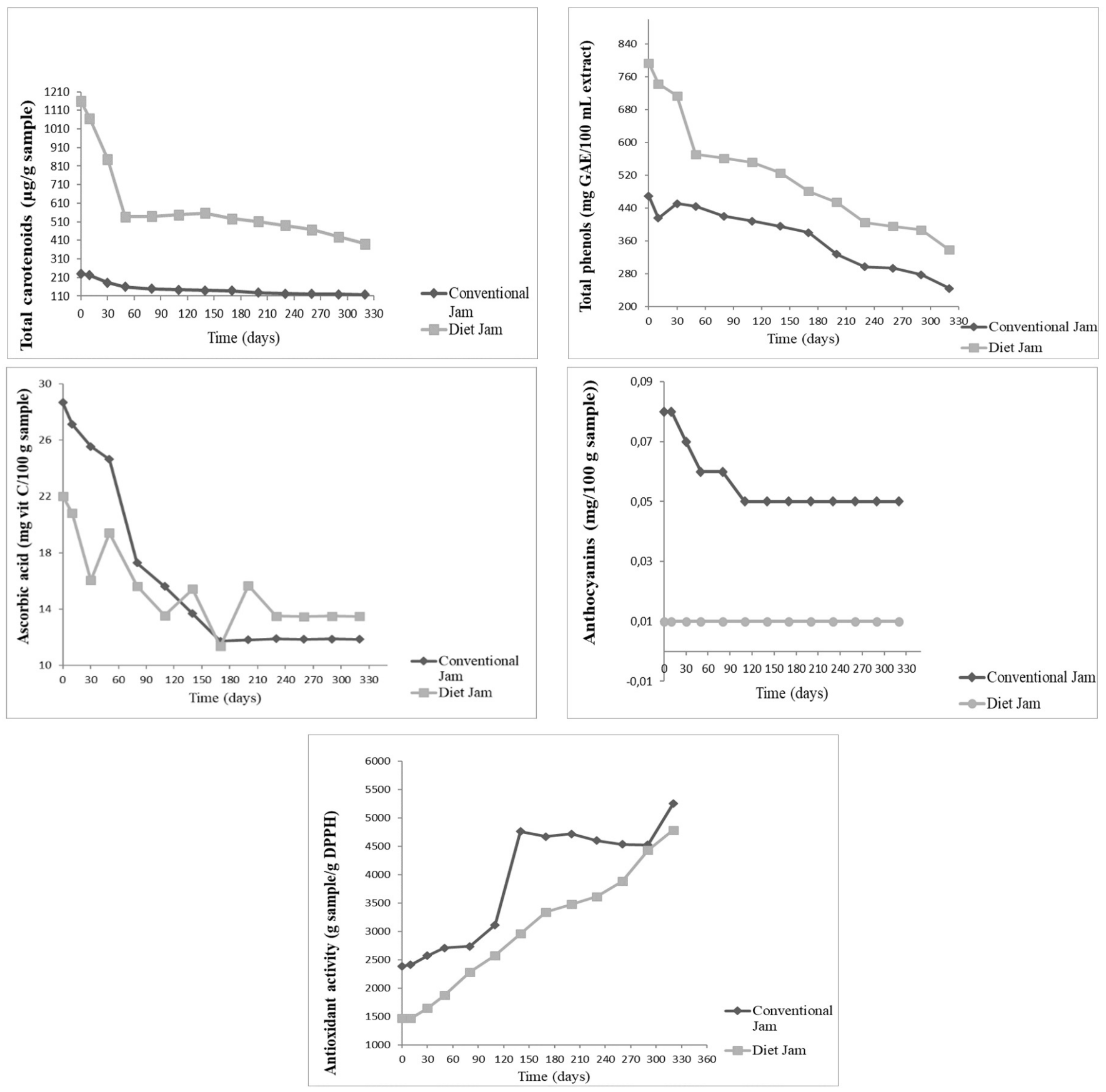

Figure 1. Effect of storage for 320 days on the carotenoid, phenol, ascorbic acid and anthocyanin contents as well as on the antioxidant activity of conventional and diet pitanga jams.

jam, particularly in the initial 40 days of storage. A decrease in anthocyanins has also been found after 180 days of storage at $10^{\circ} \mathrm{C}$ and $25^{\circ} \mathrm{C}$ for conventional and light blackberry jams with the highest loss (an 80\% decrease) in traditional jam stored at $25^{\circ} \mathrm{C}$ and a $19 \%$ loss in the diet jam (Moura et al., 2012). Light, temperature and storage time can significantly affect the stability and colour of jams, and a higher anthocyanin content has been found in jam samples stored at lower temperatures and protected from light (Cardoso et al., 1997). Processing jam with sweeteners in place of sucrose also has an effect on the pigment preservation in jam. Specifically, sweeteners do not significantly change the anthocyanin content compared with jam made with sucrose, which results in products with less pronounced darkening (Mota, 2007) and may explain the stability of the anthocyanin content in the diet jam in the present study.

The antioxidant activity was reduced in the conventional jam beginning at 110 days of storage and then remained constant between 140 and 320 days, whereas the diet jam had already exhibited a decrease at 50 days of storage. At the end of the storage period, the conventional and diet jams exhibited a total 
Tobal; Rodrigues

Table 3. Sensory acceptability of conventional and diet pitanga jams (mean \pm standard deviation) after preparation and after 320 days of storage.

\begin{tabular}{lccccc}
\hline \multirow{2}{*}{ Attribute } & \multicolumn{2}{c}{ Conventional Jam } & & \multicolumn{2}{c}{ Diet Jam } \\
\cline { 2 - 3 } \cline { 5 - 6 } \cline { 5 - 6 } Colour & Preparation & Storage & & Preparation & $5.29 \pm 1.81^{\mathrm{b}}$ \\
Appearance & $7.63 \pm 1.18^{\mathrm{a}}$ & $7.51 \pm 1.27^{\mathrm{a}}$ & & $6.35 \pm 1.81^{\mathrm{a}}$ & $5.13 \pm 1.90^{\mathrm{b}}$ \\
Aroma & $7.53 \pm 1.16^{\mathrm{a}}$ & $7.51 \pm 1.23^{\mathrm{a}}$ & & $6.45 \pm 1.74^{\mathrm{a}}$ & $5.84 \pm 1.69^{\mathrm{b}}$ \\
Flavour & $7.00 \pm 1.28^{\mathrm{a}}$ & $7.19 \pm 1.25^{\mathrm{a}}$ & & $6.42 \pm 1.64^{\mathrm{a}}$ & $5.66 \pm 2.01^{\mathrm{a}}$ \\
Texture & $6.86 \pm 1.79^{\mathrm{a}}$ & $7.40 \pm 1.40^{\mathrm{b}}$ & & $5.03 \pm 2.00^{\mathrm{a}}$ & $5.58 \pm 1.84^{\mathrm{b}}$ \\
Overall acceptance & $7.38 \pm 1.37^{\mathrm{a}}$ & $7.36 \pm 1.47^{\mathrm{a}}$ & & $6.46 \pm 1.71^{\mathrm{a}}$ & $5.08 \pm 1.87^{\mathrm{b}}$ \\
\hline
\end{tabular}

Means followed by different letters in the same column differ significantly according to Tukey's test $(p \leq 0.05)$.

decrease in antioxidant activity of $54.56 \%$ and $69.32 \%$, respectively. Kopjar et al. (2016) studied the influence of trehalose on the antioxidant activity, colour and texture of orange jam during storage and found that phenolic compounds and antioxidant activity were decreased after 135 days of storage in jams both supplemented and not supplemented with trehalose. Given that some studies have found a decrease in antioxidant activity and others have found an increase in antioxidant activity in jams during storage, the authors argue that changes in antioxidant activity may be caused by a degradation or chemical alteration of antioxidants, but that new antioxidants can be formed during storage as a consequence of Maillard reactions or interactions among ingredients (Kopjar et al., 2016).

The stability of bioactive compounds in foods during storage has been the subject of many studies. Silva et al. (2010) found a decrease in the vitamin $C$ content of guava juice during 250 days of storage with a $36.3 \%$ decrease for the hot fill process and a $34.9 \%$ decrease for the aseptic method. Moreover, Carneiro et al. (2016) assessed the number of bioactive compounds in blackberry jams during storage for 120 days and found a decrease in total anthocyanin and vitamin C levels. Rababah et al. (2011) found a reduction in anthocyanin content, phenolic compound content and antioxidant activity during the storage of jams made from five types of fruits for 5 months. The present study found that all of the assessed bioactive compounds and antioxidant activity decreased over the course of 320 days of storage. These results indicated that the consumption of newly produced jam is most desirable, but that bioactive compounds are still present in good amounts even after storage.

The feasibility of different storage conditions should be investigated to optimise the conservation of bioactive compounds, given the results from existing studies on the use of sweeteners instead of sucrose (Moura et al., 2012; Kopjar et al., 2016), storage at low temperatures (Moura et al., 2012), light conditions during storage and the type of packaging (Carneiro et al., 2016).

\subsection{Evaluation of sensory acceptability}

With regard to sensory acceptability, all of the attributes of conventional jam received a mean score greater than 6.8 (Table 3), which ranged between "like slightly" and "like extremely" and indicated good acceptance. For the diet jam, the means obtained for colour, appearance, aroma and texture of the recently prepared jam were greater than 6 (Table 3), indicating good acceptance.
However, flavour and overall acceptance scored below 6 (Table 3), which correspond to "neither like nor dislike".

The storage of conventional pitanga jam only had a significant influence on the flavour attribute, which had a higher acceptance after 320 days of storage. In contrast, the sensory acceptance of the diet jam was significantly lower after storage with respect to all attributes, except flavour. The lower acceptance of the colour of this jam may have been due to the lower carotenoid content, which leads to loss in food colour, thus influencing the appearance and overall acceptance (Zepka \& Mercadante, 2009).

In a study performed with formulations of mixed acerola and pitanga jams, pitanga had a positive influence on sensory acceptance (Melo et al., 1999). The attributes of flavour and overall acceptance were lower in the diet jam, which may have been due to the sweeteners used in the formulation. In other studies performed with diet pineapple and cubiu jam, the sensory acceptance was better, but the sweeteners used were different from those used in this study (Yuyama et al., 2008; Rosa et al., 2011). Thus, it would be interesting to develop different formulations of diet pitanga jam to test other sweeteners.

\section{Conclusion}

The preparation of jams is a feasible alternative use of pitanga given the physical, chemical, nutritional and sensory results observed. The diet jam not only exhibited a lower energy value but also had higher levels of bioactive compounds, antioxidant activity and nutrients compared with the traditional jam.

Storage time did not result in any important changes in the physical and nutritional characteristics, but it had a significant effect on the number of bioactive compounds in and the antioxidant activity of pitanga jam, and the contents of these components decreased over time.

The results suggest that consumers need to be aware of the possible consequences of long-term storage of jams. Thus, even with no changes in nutrients, the quality of jams is compromised because bioactive compounds have a positive impact on health.

\section{Acknowledgements}

The authors thank the Brazilian Agency for the Improvement of Higher Education (Conselho Nacional de Desenvolvimento Científico e Tecnológico - CNPq under Grant 477739/2013-0) and the Federal University of Grande Dourados for financial support. 


\section{References}

Association of Official Analytical Chemists - AOAC. (1990). Official methods of analyses of Association of Analytical Chemist (15th ed.). Washington: AOAC.

Association of Official Analytical Chemists - AOAC. (1997). Official methods of analyses of Association of Analytical Chemist (16th ed.). Washington: AOAC.

Bobbio, F. O., \& Bobbio, P. A. (2003). Pigmentos naturais. In Introdução à Química de Alimentos (3. ed.). São Paulo: Livraria Varela.

Brand-Williams, W., Cuvelier, M. E., Berset, C. (1995). Use of a free radical method to evaluate antioxidant activity. Food Science and Technology, 28, 25-30.

Cardoso, R. L., Ferreira, V. L. P., Montgomery, M. W., Yotsuyanagi, K., \& Sarakham, M. (1997). Effects of time, light and temperature on the red jambo (Eugenia malaccensis, Lin) jam colour. Food Science and Technology, 17, 28-31.

Carneiro, L. M., Pires, C. R. F., Lima, J. P., Pereira, P. P. A., \& Lima, L. C. O. (2016). Evaluation of stability of blackberry jams conditioned in different packaging materials. Journal of Bioenergy and Food Science, 3, 89-102. http://dx.doi.org/10.18067/jbfs.v3i2.99.

Cieślik, E., Gręda, A., \& Adamus, W. (2006). Contents of polyphenols in fruit and vegetables. Food Chemistry, 94(1), 135-142. http://dx.doi. org/10.1016/j.foodchem.2004.11.015.

Consolini, A. E., \& Sarubbio, M. G. (2002). Pharmacological effects of Eugenia uniflora (Myrtaceae) aqueous crude extract on rats heart. Journal of Ethnopharmacology, 81(1), 57-63. http://dx.doi. org/10.1016/S0378-8741(02)00039-9. PMid:12020928.

Costa, C. O. M., Maia, G. A., Figueiredo, R. W., Souza Filho, M. S. M., \& Brasil, I. M. (2003). Storage stability of cashew apple juice preserved by hot fill and aseptic processes. Food Science and Technology, 23(Suppl.) 106-109. http://dx.doi.org/10.1590/S0101-20612003000400020.

De Lima, V. L. A. G., Mélo, E. A., \& Lima, D. E. S. (2002). Total phenolics and carotenoids in Surinam cherry. Scientia Agrícola, 59, 447-450.

Derivi, S. C. N., \& Mendez, M. H. M. (2001). Uma visão retrospectiva da fibra e doenças cardiovasculares. São Paulo: Varela.

Di Matteo, V., \& Esposito, E. (2003). Biochemical and therapeutic effects of antioxidants in the treatment of Alzheimer's disease, Parkinson's disease, and amyotrophic lateral sclerosis. Current Drug Targets. CNS and Neurological Disorders, 2(2), 95-107. http://dx.doi. org/10.2174/1568007033482959. PMid:12769802.

Ewald, C., Fjelkner-Modig, S., Johansson, K., Sjöholm, I., \& Åkesson, B. (1999). Effect of processing on major flavonoids in processed onions, green beans, and peas. Food Chemistry, 64(2), 231-235. http://dx.doi.org/10.1016/S0308-8146(98)00136-8.

Freitas, C. A. S., Maia, G. A., Costa, J. M. C., Figueiredo, R. W., Rodrigues, M. C. P., \& Sousa, P. H. M. (2006a). Storage stability of acerola tropical fruit juice obtained by hot fill method. International Journal of Food Science \& Technology, 41(10), 1216-1221. http:// dx.doi.org/10.1111/j.1365-2621.2006.01188.x.

Freitas, C. A. S., Maia, G. A., Costa, J. M. C., Figueiredo, R. W., Sousa, P. H. M., \& Fernandes, A. G. (2006b). Stability of carotenoids, anthocyanins and vitamin $C$ presents in acerola sweetened tropical juice preserved by hot fill and aseptic processes. Ciência e Agrotecnologia, 30(5), 942-949. http://dx.doi.org/10.1590/S1413-70542006000500018.

Granada, G. G., Zambiazi, R. C., Mendonça, C. R. B., \& Silva, E. (2005). Physical, chemical, microbiological and sensory characterisation of light jellies of pineapple. Food Science and Technology, 25(4), 629-635. http://dx.doi.org/10.1590/S0101-20612005000400002.
Kiralp, S., \& Toppare, L. (2006). Polyphenol content in selected Turkish wines, an alternative method of detection of phenolics. Process Biochemistry, 41(1), 236-239. http://dx.doi.org/10.1016/j. procbio.2005.06.011.

Kopjar, M., Pichler, A., Turi, J., \& Pilizota, V. (2016). Influence of trehalose addition on antioxidant activity, colour and texture of orange jelly during storage. International Journal of Food Science \& Technology, 51(12), 2640-2646. http://dx.doi.org/10.1111/ijfs.13250.

Kris-Etherton, P. M., Hecker, K. D., Bonanome, A., Coval, S. M., Binkoski, A. E., Hilpert, K. F., Griel, A. E., \& Etherton, T. D. (2002). Bioactive compounds in foods: Their role in the prevention of cardiovascular disease and cancer. The American Journal of Medicine, 113(9, Suppl 9B), 71S-88S. http://dx.doi.org/10.1016/S0002-9343(01)00995-0. PMid:12566142.

Kuskoski, E. M., Asuero, A. G., Morales, M. T., \& Fett, R. (2006). Wild fruits and pulps of frozen fruits: Antioxidant activity, polyphenols and anthocyanins. Ciência Rural, 36(4), 1283-1287. http://dx.doi. org/10.1590/S0103-84782006000400037.

Lago, E. S., Gomes, E., \& Silva, R. (2006). Production of jambolan (Syzygium cumini Lamarck) jelly: Processing, physical-chemical properties and sensory evaluation. Food Science and Technology, 26(4), 847-852. http://dx.doi.org/10.1590/S0101-20612006000400021.

Laorko, A., Tongchitpakdee, S., \& Youravong, W. (2013). Storage quality of pineapple juice non-thermally pasteurized and clarified by microfiltration. Journal of Food Engineering, 116(2), 554-561. http://dx.doi.org/10.1016/j.jfoodeng.2012.12.033.

Maciel, M. I. S., Melo, E. A., Lima, V. L. A. G., Silva, W. S., Maranhão, C. M. C., \& Souza, K. A. (2009). Sensory and physico-chemical characterisation of mixed mango and acerola jam. Boletim do Centro de Pesquisa e Processamento de Alimentos, 27(2), 247-256.

Meilgaard, M., Civille, G. V., \& Carr, B. T. (1999). Sensory evaluation techniques (3rd ed.). Boca Raton: CRC Press. http://dx.doi. org/10.1201/9781439832271.

Melo, E., Lima, V. L. A. G., Nascimento, P. P. (1999). Formulation and physicochemical and sensory evaluation of mixed Surinam cherry (Eugenia uniflora L.) and acerola (Malpighia sp) Jam. Boletim do Centro de Pesquisa e Processamento de Alimentos, 17(1), 33-44.

Mota, R. V. (2006). Physical and chemical characterisation of blackberry jam. Food Science and Technology, 26(3), 539-543. http://dx.doi. org/10.1590/S0101-20612006000300009.

Mota, R. V. (2007). Chemical Characterization and Acceptability of Blackberry Low Soluble Solids Jellies. Brazilian Journal of Food Technology, 10, 116-121.

Moura, S. C. S. R., Tavares, P. E. R., Germer, S. P. M., Nisida, A. L. A. C., Alves, A. B., \& Kanaan, A. S. (2012). Degradation Kinetics of Anthocyanin of Traditional and Low-Sugar Blackberry Jam. Food and Bioprocess Technology, 5(6), 2488-2496. http://dx.doi.org/10.1007/ s11947-011-0578-7.

Nachtigall, A. M., Souza, E. L., Malgarim, M. B., \& Zambiazi, R. C. (2004). Light blackberry jellies. Boletim do Centro de Pesquisa e Processamento de Alimentos, 22(2), 337-354.

Polesi, L. F., Da-Matta, M. D. Jr, \& Matsuoka, C. R. (2011). Caracterização química e física de geleia de manga de baixo valor calórico. Revista Brasileira de Produtos Agroindustriais, 13(1), 85-90. http://dx.doi. org/10.15871/1517-8595/rbpa.v13n1p85-90.

Rababah, T. M., Al-Mahasneh, M. A., Kilani, I., Yang, W., Alhamad, M. N., Ereifej, K., \& Al-U'datt, M. (2011). Effect of jam processing and storage on total phenolics, antioxidant activity, and anthocyanins of different fruits. Journal of the Science of Food and Agriculture, 91(6), 1096-1102. http://dx.doi.org/10.1002/jsfa.4289. PMid:21254073. 
Raj, P. A. A., Radha, K., Vijayalakshmi, M., Pavulra, S., \& Anuradha, P. (2017). Study on the utilization of paneer whey as functional ingredient for papaya jam. Italian Journal of Food Science, 29(1), 171-185.

Rodriguez-Amaya, D. B. (2001). A guide to carotenoid analysis in foods. Washington: ILSI. $64 \mathrm{p}$.

Rosa, N. C., Trintim, L. T., Corrêa, R. C. G., Vieira, A. M. S., Bergamasco, R. (2011). Development of zero sugar pineapple and mint jam: processing, physicochemical parameters and sensory analysis. Revista Tecnológica, 83-89.

Rutz, J. K., Voss, G. B., Jacques, A. C., Pertuzatti, P., Barcia, M. T., \& Zambiazi, R. C. (2012). Physalis peruviana L. jelly: Bioactive, antioxidant and sensory characterisation. Alimentos e Nutrição, 23, 369-375.

Serafini, M., Bellocco, R., Wolk, A., \& Ekström, A. M. (2002). Total antioxidant potential of fruit and vegetables and risk of gastric cancer. Gastroenterology, 123(4), 985-991. http://dx.doi.org/10.1053/ gast.2002.35957. PMid:12360458.

Silva, D. S., Maia, G. A., Sousa, P. H. M., Figueiredo, R. W., Costa, J. M. C., \& Fonseca, A. V. V. (2010). Stability of bioactive compounds of unsweetened tropical guava juice obtained by hot fill and aseptic processes. Food Science and Technology, 30, 237-243.

Souza, V. R., Pereira, P. A. P., Teixeira, T. R., Silva, T. L. T., Pio, R., \& Queiroz, F. (2015). Influence of processing on the antioxidant capacity and bioactive compounds in jellies from different blackberry cultivars. International Journal of Food Science \& Technology, 50(7), 1658-1665. http://dx.doi.org/10.1111/ijfs.12819.

Toneli, J. T. C. L., De Murr, F. E. X., \& Park, K. J. (2005). Study of the rheology of polysaccharides used in the food industry. Revista Brasileira de Produtos Agroindustriais, 7, 181-204. http://dx.doi. org/10.15871/1517-8595/rbpa.v7n2p181-204.

Wu, R., Frei, B., Kennedy, J. A., \& Zhao, Y. (2010). Effects of refrigerated storage and processing technologies on the bioactive compounds and antioxidant capacities of 'Marion' and 'Evergreen' blackberries. Lebensmittel-Wissenschaft + Technologie, 43(8), 1253-1264. http:// dx.doi.org/10.1016/j.lwt.2010.04.002.

Yamashita, F., Benassi, M. T., Tonzar, A. C., Moriya, S., \& Fernandes, J. G. (2003). West indian cherry products: Study of vitamin C stability. Food Science and Technology, 23(1), 92-94.

Yuyama, L. K. O., Pantoja, L., Maeda, R. N., Aguiar, J. P. L., \& Da-Silva, S. B. (2008). Development and acceptability of a low calorie cubiu (Solanum sessiliflorum Dunal) jam. Food Science and Technology, 28(4), 929-934. http://dx.doi.org/10.1590/S0101-20612008000400026.

Zepka, L. Q., \& Mercadante, A. Z. (2009). Degradation compounds of carotenoids formed during heating of a simulated cashew apple juice. Food Chemistry, 117(1), 28-34. http://dx.doi.org/10.1016/j. foodchem.2009.03.071. 